\title{
Van Christologie tot Jesulogie? Teologiese gesprek met Sakkie Spangenberg na aanleiding van sy boek Jesus van Nasaret (2009)
}

\author{
Author: \\ Jan Harm van Wyk ${ }^{1}$ \\ Affiliation: \\ ${ }^{1}$ Unit for Reformed Theology, \\ North-West University, \\ Potchefstroom Campus \\ South Africa \\ Correspondence to: \\ Amie van Wyk \\ Email: \\ amiejanvw@gmail.com \\ Postal Address: \\ PO Box 11692, Silver Lakes, \\ Pretoria 0054, South Africa \\ Dates: \\ Received: 15 Mar. 2011 \\ Accepted: 25 Aug. 2011 \\ Published: 05 Nov. 2012 \\ How to cite this article: \\ Van Wyk, J.H., 2012, 'Van \\ Christologie tot Jesulogie? \\ Teologiese gesprek met \\ Sakkie Spangenberg na \\ aanleiding van sy boek Jesus \\ van Nasaret (2009)', In die \\ Skriflig/In Luce Verbi 46(1), \\ Art. \#46, 11 pages. http:// \\ dx.doi.org/10.4102/ids. \\ v46i1.46
}

Spangenberg het 'n boeiende boek oor Jesus van Nasaret geskryf waarin hy aandag skenk aan onder meer (vermeende) Ou-Testamentiese agtergronde, om daarna veral dieper in te gaan op verskeie Nuwe-Testamentiese perspektiewe op Jesus. Hy het tot die konklusie gekom dat die onderskeie Nuwe-Testamentiese skrywers elk 'n eie perspektief op Jesus ontwikkel het, perspektiewe wat mekaar soms weerspreek. In elk geval was daar 'n groot verskil tussen die historiese Jesus van Nasaret en die dogmatiese Jesus van die kerklike belydenis. In die kerklike dogma is Jesus vergoddelik, iets wat Hy nooit was of wou wees nie. Die ware Jesus was niemand anders nie as ' $n$ Joodse profeet en wysheidsleermeester. Spangenberg kom tot hierdie gevolgtrekking op grond van wat hy noem 'wetenskaplike studie' en 'n radikaalkritiese omgang met die Bybel. In hierdie artikel is sowel die filosofiese vertrekpunte as die teologiese konklusies van Spangenberg krities bespreek en bevraagteken.

From Christology to Jesuology? Theological discussion with Sakkie Spangenberg with reference to his book Jesus van Nasaret (2009). Spangenberg wrote a riveting book on Jesus of Nazareth in which he paid attention to inter alia (alleged) Old Testament background and then proceeded to a more in-depth investigation into several New Testament perspectives on Jesus. He came to the conclusion that the different New Testament authors each developed their own perspective on Jesus, perspectives which were sometimes contradictory. He found a huge difference between the historical Jesus of Nazareth and the dogmatic Jesus of the church confessions. In this church tenet Jesus was deified, something He was not, neither wanted to be. The true Jesus was none other than a Jewish prophet and wisdom teacher. Spangenberg reached this conclusion on the basis of what he called 'scientific' study and a radically critical way of dealing with the Bible. In this article both the philosophical points of departure and the theological conclusions of Spangenberg were discussed and queried critically.

\section{Inleiding}

Dit is ongetwyfeld só dat die debat oor wie Jesus van Nasaret was (of is) skynbaar sonder einde is en klaarblyklik ook vir altyd so gaan wees. Die debat het veral sedert die Aufklürung met sy rasionalistiese vertrekpunt nuwe momentum gekry en hier kan slegs verwys word na die wendings wat Reimarus (1694-1768) en D.F. Strauss (1808-1874) hieraan gebring het. (Strauss het uiteindelik 'n ateïs geword en het ook 'n groot invloed op Karl Marx gehad wat ook 'n ateïs geword het.)

In die 20ste eeu het die groot Duitse Nuwe-Testamentikus, Rudolf Bultmann (1884-1976), die ontmitologiseringsprogram in die Christologie die verste deurgevoer met sy radikale skeiding van die historiese Jesus en die opgestane Christus; as gevolg waarvan die liggaamlike opstanding van Jesus weggeval het. Wat opgestaan het, is nie die historiese Jesus self nie, maar wat in die hárt van die mens moet opstaan, is die boodskap van Godsvertroue en medemenslikheid wat in die historiese Jesus te sien was.

In 1985 het 'n beweging genaamd die 'Jesus Seminar' in die VSA ontstaan en in 2002 die Nuwe Hervorming $(\mathrm{NH})$ in Suid-Afrika. Hierdie bewegings vind in 'n groot mate aansluiting by die ontmitologiseringsprogram van Bultmann, alhoewel hulle veel meer klem lê op die Joodsheid van Jesus as wat Bultmann gedoen het. Spangenberg (2002a:88-111) posisioneer hom ondubbelsinnig binne hierdie denktradisie. Daar is ook ander teoloë in Suid-Afrika wat by hierdie benadering aansluiting vind, trouens die stroom van boeke oor wie Jesus werklik was (is), is redelik omvattend en wissel van aansluiting by Bultmann tot verwerping van hom. ${ }^{1}$

1.Vergelyk in hierdie verband die talle studies oor Jesus wat die afgelope dekade deur Suid-Afrikaanse teoloë gepubliseer is: Janson (2001) Van Aarde (2001); König (2001; 2010b); Du Plessis (2005); Wessels (2006); Craffert (2008); Schutte (2008); Spangenberg (2009); Joubert (2009); Van der Watt, Joubert, Tolmie en De Villiers (2010). Vergelyk verder ook Nolan (1976; 2006); Jonker (1977); Mofokeng (1983); Du Toit (1997); Van der Walt (2006). Joubert (2009:77-78, 132, 188, 197-198) merk op dat dit in ons Jesus-belangstelling veral oor 'verhoudings' moet gaan en nie oor 'dogmas' nie, maar 'n 'dogmalose' Jesus is nie teologies haalbaar of wenslik nie. 
In hierdie artikel word spesifiek op een van hierdie geskrifte gefokus, naamlik dié van Spangenberg, ${ }^{2}$ alhoewel daar ook na van die ander geskrifte van Spangenberg verwys sal word. Verder word ook net terloops na die bydraes van Botha (oor Markus) en Jacobs (oor Johannes) verwys.

Vir' $n$ sinvolle debatvoering met Spangenberg, is dit belangrik om die paradigma waarbinne hy teologiseer, naamlik die paradigma van die Nuwe Hervorming $(\mathrm{NH})$, duidelik voor oё te hou. Hierdie beweging aanvaar nie so iets soos 'n belydenisskrif of dogma nie, maar wel, wat hulle noem, 'n stel Waardes wat soos volg lui (Spangenberg 2010a):

- Ons aanvaar dat wanneer ons oor die goddelike praat, ons na die onbegryplike misterie van die lewe verwys, wat ons onder andere in Jesus van Nasaret leer ken.

- Ons koester die beste van ons erfgoed in onder andere die Bybel, ons Christelike en ander spirituele tradisies. Dieselfde geld vir ons nalatenskap op die gebied van musiek, kuns, letterkunde en wetenskap.

- Ons maak nie aanspraak op ewige waarhede nie maar neem die huidige wêreldbeeld ernstig op.

- Ons waardeer die uniekheid, eiewaarde, gelykheid en potensiaal van elke individu. Ons erken die inherente vermoë van individue om te groei en om groter hoogtes te bereik deur met mekaar saam te werk.

- Ons aanvaar verantwoordelikheid vir onsself, en teenoor ons medemens en ons natuurlike omgewing. Ons streef daarna om met morele integriteit op te tree.

- Ons streef daarna om medemenslik en verdraagsaam teenoor alle mense op te tree, ongeag geslag, seksuele oriëntasie, geloofsoriëntasie, fisieke vermoë, en groepsverband.

- Ons bevorder kreatiewe en innoverende denke.

- Ons beskou diversiteit en godsdienstige pluralisme as positiewe verskynsels.

- Ons verbind ons tot 'n etos van samewerking.

\section{Voorveronderstellings: Naïewe rasionalisme en positivisme}

Een van die groot vrae in die teologie vandag hou verband met die vraag vanuit watter (filosofiese) voorveronderstellings 'n teoloog sy teologie beoefen. Daar is immers geen teoloog wat nie, bewus of onbewus, vanuit bepaalde presupposisies teologiseer nie. So is 'n teoloog se Skrifbeskouing byvoorbeeld bepalend vir sy teologiese konklusies.

Jonker (1977:160) maak iewers tereg die opmerking dat baie van die verskille tussen die klassieke Christologiese opvattings en die moderne opvattings toegeskryf kan

2.Botha (oor Markus) en Jacobs (oor Johannes) het ook hierin bydraes gelewer, terwyl een hoofstuk (oor Lukas) saam deur Botha en Spangenberg geskryf is. Vergelyk in hierdie verband ook die ondersoekende boek van McLaren (2010), hoewel sy herinterpretasie van die Evangelie nie so ver gaan as dié van Spangenberg nie. Ek het hierdie artikel voor publikasie aan Spangenberg vir kommentaar gestuur en sy reaksie daarop was die volgende: 'Jou weergawe van my standpunte is billik en nie reaksie daarop was die volgende: 'Jou weergawe van my standpunte is billik en nie verwronge nie." "Dit is ' $n$ baie goeie en verantwoordelike bespreking van die boek en die standpunte wat daarin verwoord word. Jy oordeel ook billik oor my sienings' (epos aan my op 19 Julie 2011). Graag dra ek hierdie artikel ook aan my kollega, Koos Vorster, op uit dank en waardering vir sy besondere en konstruktiewe bydrae in die
Koninkryk, kerk en teologie.

3.Vergelyk hier Bavinck (1928:186-207) se bespreking van die rasionalisme, empirisme en realisme. word aan die verskuiwings wat daar met betrekking tot die omgang met die Skrif ingetree het (vgl. Polman s.a.:15-16). Die radikale Skrifkritiek wat veral sedert die Aufklärung na vore getree het, het ' $n$ totaal ander verhaal oor wie Jesus was, gekonstrueer. Dit blyk ook baie duidelik uit die tweede en derde Waarde van die NH; die Bybel is 'n boek 'onder andere' en daar bestaan ook nie so iets soos 'ewige waarhede' nie. Die enigste vaste, absolute en onomstootlike waarheid van die $\mathrm{NH}$ is: daar bestaan geen vaste waarhede nie. ${ }^{4}$

Van die drie moontlike standpunte oor die Bybel, naamlik (1) die Bybel is Woord van God, (2) die Bybel is die Woord van God in mensetaal en (3) die Bybel bevat (slegs) menslike gedagtes oor God (of 'die goddelike'), ${ }^{5}$ kies Spangenberg baie duidelik vir die derde benadering: 'Dit wat ons in die Bybel vind, is nie openbaring van God nie, maar mense se nadenke oor God.' (Spangenberg 2010a). ${ }^{6}$ 'Wanneer ek die Bybel bestudeer, bestudeer ek dit as 'n menslike geskrif wat deur mense geskryf en saamgestel is' (Spangenberg 2010b).

Hoewel Spangenberg (aanvanklik altans) van die Bybel as 'n 'basisdokument' van die Christelike geloof en godsdiens praat (1998:110, 115; 2002a:109), beskou hy tog die Bybel as 'n boek 'onder andere'. Dit besit dus nie normatiewe gesag nie en is daarom, minstens teoreties, nie 'n belangriker teks as byvoorbeeld Plato se Politeia, Mohammed se Koran, Cervantes se Don Quixote, Heidegger se Sein und Zeit en Hawking se A Brief History of Time nie.

In sy boek oor Jesus van Nasaret, spel Spangenberg sy siening oor die Bybel in sy slothoofstuk baie duidelik uit: 'Alles wat in die Bybel oor God en Jesus geskryf staan, is deur mense geskryf. Alles wat in die Christelike tradisie oor God, Jesus en die Gees gesê en geskryf is, is deur mense gesê en geskryf' (Spangenberg 2009:359). ${ }^{7}$ Die Bybel is ' $n$ 'versameling van menslike geskrifte' (ibid. 2009:360) en die Ou Testament 'n 'versameling uiteenlopende Joodse geskrifte sonder sentrale tema' (ibid. 2009:360). Soos 'n refrein word dit telkens herhaal: 'Die Bybel [is] 'n versameling antieke godsdienstige geskrifte wat deur gewone mense geskryf is' (ibid. 2009:365). ${ }^{8}$ Die wetenskaplike rewolusie van die sestiende en sewentiende eeue, die groeiende historiese bewussyn van die sewentiende en die agtiende eeue, die ewolusieteorie van Darwin in die negentiende eeu, die moderne wetenskaplike ondersoek van die Bybel en die omwentelinge in die fisika en meganika het alles verander (ibid. 2009:364), ook ons siening en

4.Laasgenoemde uitspraak is natuurlik' $n$ contradictio in terminis, aangesien dit juis as waarheidsuitspraak aangedien word. Vergelyk ook Spangenberg (2002c:100-117).

5.Vergelyk Spangenberg 1998:30-34.

6.Ek het toestemming by Spangenberg gevra om van ons epos korrespondensie gebruik te maak: 'Jy is welkom om uit die briefwisseling tussen my en jou aan te haal en na goeddunke gebruik te maak' (epos aan my op 22 November 2010).

7.Vergelyk hier die bekende uitspraak van Kuitert (1974:28): 'Alle spreken van boven komt van beneden, ook de uitspraak dat iets van boven komt.' Die 'Christologie' van Spangenberg vertoon groot verwantskap met die kritiese 'Christologie' van Kuitert (1998).

8.'Die Bybel is ' $n$ versameling van Nabye-Oosterse godsdienstige geskrifte wat deur beperkte, feilbare mense geskryf is ... Die geskrifte bevat die geloofsinsigte en
beper geloofsgetuienisse van daardie mense en hulle tydgenote' (Spangenberg 1994:156; geloofsgetuienisse van daardie mense en hulle tydgenote (Spangenberg 1994:156;
kursivering deur Spangenberg). Dieselfde gedagte is ook te vind in Spangenberg $(1998: 24,28)$ 
verstaan van die Bybel. Die afskeid van die drie-verdieping wêreldbeeld (ibid. 2009:105-106) het enorme konsekwensies met hom meegebring.

Dit is duidelik dat die Bybel 'n gewoon menslike boek is en moet op 'n gewoon menslike manier verstaan word.

Hiermee word natuurlik 'n radikale breuk met twee duisend jaar se teologie- en kerkgeskiedenis voltrek. Anders as in die Rooms-Katolieke Kerk waar aan die Bybel normatiewe gesag toegeken word, weliswaar sáám met die Tradisie, ${ }^{9}$ en anders as in die Oosters Ortodokse kerke waar uitgegaan word van die 'supreme authority and primacy of scripture' (Stylianopoulos 2008:21, 25), én anders as in die kerke van die Reformasie wat bely dat die Heilige Skrif die wil van God volkome bevat (NGB art. 3, 5, 7), aanvaar die NH die Bybel as gewoon 'n menslike boek, vol foute, leemtes en teenstrydighede (Spangenberg 2009:53, 58, 213, 359, 360). In kort, 'n boek waarop jy jou nie kan verlaat nie, 'n boek 'onder andere'.

Die vraag is nou: wat bring Spangenberg tot hierdie konklusie, hierdie breuk met 2000 jaar se kerk- en teologiegeskiedenis, hierdie radikale diskontinuïteit in Skrifbeskouing en Skrifverklaring?

Die antwoord is eenvoudig, wetenskaplike studie. Terwyl die Katolieke, maar ook die Oosters Ortodoksie tradisie (Stylianopoulos 2008:24), veral die kérk as die finale interpreteerder van die Bybel sien, en in die Reformatoriese tradisie meer ruimte gemaak word vir die Gees deur verligte individu, soek Spangenberg die antwoord by wetenskaplike navorsing. Minstens dertien keer word dit herhaal. ${ }^{10}$ Die wetenskaplike proses werk dan so dat dit met raaiskote begin en dat die raaiskote eers feite word na deeglike wetenskaplike toetsing (Spangenberg 2009: 147-148).

'n Nuwe gesaghebbende vertolker van die Bybel het tans ontstaan. Dit is nie meer die kerk van alle eeue nie, selfs nie die kerk onder leiding van die Heilige Gees nie, ook nie meer die individu onder leiding van die Gees nie, maar die teologiese wetenskap onder leiding van die menslike verstand en die verifikasieprinsipe. Van die leiding van die Gees van God by die totstandkoming en vertolking van die Bybel word by die $\mathrm{NH}$ weinig of niks gehoor nie. Vir Spangenberg is dit nie die Gees wat die kerk, en individue, in die waarheid lei nie (Joh 16:13), maar die teologiese vakwetenskaplike(s). Trouens, selfs laasgenoemde kan ook nie in die waarheid lei nie, maar slegs in waarskynlikhede, want daar bestaan nie 'ewige waarhede'

9.Vergelyk hier die RKK 1967:260: 'Die heilige teologie steun op die geskrewe woord van God, saam met die heilige oorlewering, as op haar blywende grondslag.' Die heilige Skrif is nie die enigste bron (non per solam) waaruit die Kerk haar sekerheid put omtrent die geopenbaarde nie (ibid. 1967:254) (Dekreet Dei Verbum).

10.Wetenskaplike studie toon aan dat die erfsondeleer van Augustinus foutief is (Spangenberg 2009:51); dat Daniël nie ' $n$ profetiese nie maar apokaliptiese boek
is (ibid. 2009:67); dat fundamentalisme foutief is (ibid. 2009:72); dat die Joodse uitlêers Jesaja reg verstann het en die Christene verkeerd (ibid 2009:78-79); dat dit (ibid. 2009:84); dat daar by Israel (aanvanklik) n viervlak-panteon van gode aanwesig was (ibid. 2009:101); dat on 'n radikal and ontwikkel (ibid. 2009.128), dat Hebreers, 1 en 2 Timotius, Titus en 2 Tessalonisense nie deur Paulus geskryf is nie (ibid. 2009:136-137); dat Matteus en Lukas vir 96\% uit Markus aanhaal (ibid. 2009:138) nie. Nêrens is daar in hierdie benadering enige sprake daarvan dat die (sentrale boodskap van die) Bybel deursigtig is of deur die Gees van God geïnspireer is nie.

Vandaar dat ek in hierdie verband na naïewe rasionalisme en positivisme verwys. Die epistemologiese model waarmee Spangenberg werk, is rasionalisme en positivisme, die model waar die menslike verstand die hoogste maatstaf en die verifikasie-prinsipe die hoogste 'norm' is (vgl. Jonker 1977:66, 76). Daar is niks, geen Bybel en geen goddelike openbaring, wat méér gesag dra as die menslike verstand en wetenskaplike bewyse nie-'n standpunt wat in die filosofie al lankal agterhaal is - te meer in 'n postmoderne tyd. ${ }^{11}$ Hierdie model werk baie duidelik met 'n geslote wêreldbeeld en dít in 'n tyd dat die moderne tegnologie en natuurwetenskap al meer van 'n oop, uitdyende en eindelose heelal vertel.

Ek tipeer hierdie standpunt as 'naïef', omdat Spangenberg klaarblyklik nie genoegsaam daarvan bewus is dat hy vanuit hierdie vertrekpunt redeneer ${ }^{12}$ nie, of hom in elk geval nie bewustelik en eksplisiet wetenskaplik daarvan rekenskap gegee het nie. ${ }^{13}$

As die teks waarmee jy werk, homself op talle plekke aandien as openbaring van God (vgl. slegs Matt 16:17; 1 Kor 12:3 en Gal 1:11-12), word daardie teks geweld aangedoen as dit slegs as bloot menslike gedagtes beskou en hanteer word. Jou Skrifbeskouing bepaal jou Skrifvertolking. ${ }^{14}$

Uit bostaande moet nie die afleiding gemaak word dat wetenskaplike navorsing nie 'n ontsaglike bydrae gelewer het om talle dele in die Bybel beter te verstaan nie. Die resultate van die wetenskaplike navorsing kan inderdaad met groot vrymoedigheid aangewend word sónder om die vertrekpunte van die (hiper-)kritiese teologie te aanvaar. Na my oordeel sal ons egter in ons Jesus-navorsing tot verantwoordeliker resultate kom indien ons die insigte van sowel die kerklike belydenisse en die teologiese tradisie, as dié van die individuele gelowige én die nuwere teologiese navorsing almal sáám in berekening bring.

\section{Wie was Jesus van Nasaret? ${ }^{15}$}

Spangenberg wys daarop dat Bybelwetenskaplikes tussen drie Jesus-beelde onderskei: (1) die historiese Jesus (soos Hy

11.Van die positivisme het een van sy belangrikste verteenwoordigers gesê: "Fifty years later, when asked what he regarded as the main defects of logical positivism he replied "Well, I suppose the most important of the defects are that nearly all of it was false"' (Ayer in Barrett 2000:134). 'Logical positivism died a long time ago' (Ayer in Flew 2008:xiv-xv).

12.Vergelyk hier Spangenberg (1994:174) se opmerking dat Bybelwetenskaplikes en sistematiese teoloë moeilik sinvolle gesprekke met mekaar kan voer, 'want hulle vertrekpunte verskil'.

13.Vergelyk in hierdie verband die opmerking van Van Niekerk (2007:681): Die basiese probleem met Spangenberg se wetenskapsbegrip is dat hy kennelik van oordeel is dat 'n suiwer tekshistoriese ondersoek genoeg 'feitelike kennis' kan oplewer om 'n ganse teologie te 'begrond' - ook al kom die somtotaal van daardie 'teologie' in wese neer op weinig minder as 'weerlegging' van die ganse tradisie van Christelike teologie.

Van Niekerk (2005:218-239) self ondervind weer probleme met die gedagte van 'lewe na die dood', maar sonder om hierdie standpunt teologies te begrond. Wessels (2006:234) verwys hier ook na Wright se opmerking oor gebrek aan 'begrip vir filosofiese problematiek' by navorsers.

14.Spangenberg stem saam: 'Jy is reg - ' $n$ mens se Skrifbeskouing en Skrifgebruik is allesoorheersend in die teologie' (epos aan my op 29 Julie 2011).

15.Vir die doel van hierdie artikel word veral gefokus op die hoofargument(e) van Spangenberg se betoog. 
as Jood in Palestina geleef en gewerk het); (2) die vertelde Jesus (dit wat die Bybelskrywers oor Hom vertel en geskryf het); en (3) die dogmatiese Jesus (dit wat die kerk later, veral in die vierde eeu, oor Hom bely het (Spangenberg 2009:6, 368-369). In 'n sekere sin sou 'n mens ook kon onderskei tussen die Jesus van die Bybelskrywers (Jesus van die 'historiese' geloof), Jesus van die kerklike dogma (Jesus van die dogmatiese geloof) en Jesus van die teologiese wetenskap (Jesus van die kritiese geloof).

Daar moet egter volgens Spangenberg 'n skerp onderskeid getref word tussen die verskillende Jesusbeelde, veral tussen die Jesus van die Bybel en die Jesus van die dogma, hoewel ons in die Bybel self ook verskillende Jesus-beelde aantref. Die Jesus van die Christendom en Jesus van Nasaret is 'nie sonder meer gelyk nie' (Spangenberg 2009:369). 'Die evangelie wat die kerk verkondig (sondeval-verlossingeindoordeel) is nie die evangelie wat Jesus verkondig het nie. ${ }^{\prime 16}$ Hierdie meesterverhaal van die Westerse Christendom is die produk van Griekse en Latynse kerkvaders en 'n ánder verhaal as dit wat ons in die Bybel aantref (ibid. 2009:29-39, 95, 360-361).

Die vraag nou, is die volgende. Hoe lyk die Jesus wat uit die Nuwe Testamentiese geskrifte na vore tree; volgens Spangenberg?

\section{Wie sê die Bybelskrywers was Jesus?}

Vir die doeleindes van hierdie artikel word slegs op die Nuwe-Testamentiese gegewens gefokus, aangesien die Ou Testament volgens Spangenberg geen profesieë bevat dat juis Jesus die Messias sou wees nie, die Nuwe-Testamentiese skrywers het die Ou Testament verdraai om by hulle 'vervulde profesieë' oor Jesus uit te kom (vgl. Spangenberg 2009:78, 81-83, 91). ${ }^{17}$

Daar is, om mee te begin, die Jesus van die Q-spreukeevangelie. Die Q-bron is daardie (verlore) oerbron wat deur die skrywers van Matteus en Lukas (naas Markus) gebruik is. Hierdie bron, meen Spangenberg, teken Jesus as gewone mens, veral as profeet en wysheidsleermeester (Spangenberg 2009:159, 161) en bevat ook nie uitsprake oor Jesus se kruisdood en opstanding nie (ibid. 2009:150).

Die Jesus-beeld wat Paulus aan ons voorhou, lyk weer anders. ${ }^{18}$ Volgens Spangenberg (2009:136) fokus Paulus op die kruis, opstanding en wederkoms van Jesus en op die Heilige Gees en nie op Jesus as profeet en wysheidsleermeester nie. Vir Paulus was Jesus se kruisdood en opstanding [sic] van 'kardinale belang', want dit bevestig dat Hy die Messias is

16.Epos aan my op 22 November 2010.

17.Aanvanklik het Spangenberg (1985:30) nog gepraat van die Christelike duiding van die Ou Testament (en ook dat Jesus Christus gekom het 'om ons te verlos', ibid. 1985:40). Vergelyk hieroor onder andere König (2010b) en uitgebreid in Satterthwaite, Hess en Wenham (1995). (Laasgenoemde verwysing met dank aan my kollega prof H.F. van Rooy.) Spangenberg $(1985: 85,99-121,327)$ is verde van oordeel dat die godsdiens van Israel aanvanklik politeïsties was en dat dit geleidelik na monoteisme ontwikkel het. Latere Bybel-redakteurs het die spore van geleidelik na monoteisme ontwikkel het. Latere Bybel-redakteurs het die spore van was (ibid. 1985:107, 110, 119). Esterhuyse (2009:34-35, 52, 102, 141, passim 2010:79) is dieselfde mening toegedaan.

18.Spangenberg bespreek nie ál Paulus se geskrifte nie. Hy behandel slegs 1 Tessalonisense, Galasiërs en Romeine en nie 1 en 2 Korintiërs, Filippense en Filemon nie (vgl. Spangenberg 2009:137). en brenger van 'n nuwe tyd vir Israel (ibid. 2009:168, 219). Die boodskap aan die Galasiërs wil sê dat nie-Jode ook deel van die volk van God kan word op grond van hulle geloof in Jesus se kruisdood (ibid. 2009:182-183). Romeine vertel ook dat alle groepe geregtigheid deur geloof in Jesus se kruisdood verkry, dit wil sê in die eindoordeel in die regte verhouding tot God sal staan (ibid. 2009:219).

Die Jesus wat die skrywer van Jakobus aan ons voorhou, ag weer die woorde van Jesus belangriker as sy kruisdood (Spangenberg 2009:231).

Vir die skrywer van Matteus was Jesus, volgens Spangenberg, 'n besondere mens, ja, 'n 'goeie humanis' (Spangenberg 2009:252, 261). Jesus was ook 'n belangrike profeet en wysheidsleermeester, selfs Messias (ibid. 2009:261, 266). Tog is die Jesus van Matteus en die Jesus van Paulus nie identies nie (ibid. 2009:267).

Lukas weer, teken Jesus as koning, profeet, Messias en Here (Spangenberg 2009:281). ${ }^{19}$ Messias beteken 'Weldoener' (ibid. 2009:282, 292). Lukas is die enigste evangelis wat Jesus 'Verlosser' noem, maar verlossing beteken dan nie verlossing van sondes nie, maar van die keiserlike oorheersing (ibid. 2009:283). Die kruisdood speel hier nie 'n reddende rol nie, maar teken Jesus as voorbeeldige martelaar (ibid. 2009:286).

Volgens Spangenberg (2009:334) sterf die Jesus van die Hebreër-brief nie aan die kruis vir ons sondes nie. Hy word ook nou iets gemaak wat Hy nooit was nie, naamlik hoëpriester (ibid. 2009:336). In hierdie brief vind ons ook die eerste tree in die rigting van die vergoddeliking van Jesus (ibid. 2009:336).

Hoe lyk die Jesus van die boek Openbaring? Volgens Spangenberg (2009:318) verskil hierdie Jesus 'radikaal' van die res van die Nuwe Testament. Jesus word hier geteken as 'n nuwe keiser wat met geweld teen sy teenstanders optree (ibid. 2009:318).

In die Nuwe Testament vind ons dus verskillende en uiteenlopende Jesus-beelde, nie komplementerend tot mekaar nie, maar kompeterend met mekaar, selfs teenstrydig met mekaar.

Hoe sou, volgens Spangenberg, die Jesusbeelde van die kerklike dogma daar uitsien?

\section{Wie was Jesus volgens die kerklike dogma?}

Spangenberg gaan in hierdie verband nie in op die moeisame proses wat die Christologiese dogma van Nicea (325), Konstantinopel (381) en Chalcedon (451) deurloop het nie (vgl. Seeberg 1964:243-288; Schulze 1978:74-115). Van die teologiese worsteling wat by die vroeë en latere kerkvaders aangetref word, is weinig te vind. ${ }^{20}$ Geen aandag word aan die

19.Ons herinner weer daaraan dat die hoofstuk oor Lukas deur Botha en Spangenberg saam geskryf is.

20.Daar word wel terloops na teoloë soos Ambrosius, Hieronimus en Augustinus (Spangenberg 2009:31) verwys, maar die name van Irenaeus, Tertullianus, Origines en Atanasius ontbreek (vgl. De Villiers in Van der Watt et al. 2010:176-181 oor die siening van die vroeë kerkvaders.). Vergelyk hier die diepsinnige uitspraak die siening van die vroee 'Kerkvaders.). Vergelyk hier die diepsinnige uitspraak become God'. Atanasius was van oordeel dat 'wie die godheid van Christus loën, become God'. Atanasius was van oordeel dat 'wie die godheid van Christus loën,
verloën alle heilsgawes' (by Polman, s.a.:9). Vir buite-Bybelse getuienis oor Jesus, vergelyk Strobel (1998:95-121) 
vraag bestee of die vroegste wortels van die Christologiese dogma nie reeds in die vroegste kerk aanwesig was, lank voordat dit dogmaties vasgelê is nie.

Ons vind ook geen diepgaande besinning oor die Christologieë van latere groot teoloë soos Augustinus, ${ }^{21}$ Thomas van Aquino, Luther, ${ }^{22}$ Calvyn, Bavinck, Barth, Bonhoeffer, Moltmann en Pannenberg nie. Spangenberg vind wel sterk aansluiting by die Christologie (eintlik Jesulogie) van Kennedy (Spangenberg 2009:361, 367). ${ }^{23}$

Van die groot Christologiese stryd van die eerste eeue word niks vertel nie, behalwe dat die Christendom die Joodse profeet Jesus in die vierde eeu 'tot 'n god omvorm het' (Spangenberg 2009:322, 362, 367). Nooit voorheen was Hy as God gesien of met God geïdentifiseer nie, nie deur Homself nie, nie deur sy dissipels nie, en ook nie deur die Vroeë Kerk nie. Filippense 2 bevat geen aanduiding in hierdie verband nie (ibid. 2009:174) - hoewel byna terloops opgemerk word dat ons reeds in Hebreërs met die eerste tree van vergoddeliking van Jesus te doen kry (ibid. 2009:336). En wat sou die implikasie daarvan wees dat Jesus na sy opstanding 'aanbid' is, soos Lukas berig (ibid. 2009:287)?

Die nuuskierige vraag dring hom op hierdie stadium vanself op. Wie wás Jesus dan nou werklik, ten minste volgens die nuwe teologiese navorsing?

\section{Wie was Jesus volgens die nuwe teologiese navorsing?}

Wie was Jesus dan werklik? Was Hy die Messias, die Seun van God, die Seun van die mens, die Here, God? En wat sou al die name en titels wat in die Nuwe Testament aan Hom toegedig word, dan beteken? En word dit deur Spangenberg in sy navorsing aan diepgaande ontleding onderwerp? ${ }^{24}$

Volgens Spangenberg (2009) word daar nêrens in die Q-bron na Jesus as Messias of Seun van God verwys nie, maar wel na Jesus as Seun van die mens. In die samelewing van daardie tyd was dit 'n algemene gebruik by mense sodat 'hierdie uitdrukking dus nie goddelikheid aandui nie' (ibid. 2009:161). Dit is opvallend dat Jesus hierdie titel graag op Homself van toepassing maak, maar dat dit later in die Nuwe Testament verdwyn. Die vraag kan gestel word of hierdie titel enigsins verband hou met 'die menslike wese' (NAV) of 'seun van die mens' (OAV, NIV, RSV) van Daniël

21.Veral Augustinus loop kwaai deur onder die pen van Spangenberg (2009:31, 51 171-172, 212, 214, 280), maar nêrens is daar enige indikasie dat Spangenberg hom intensief met die teologie van Augustinus besig gehou het nie - ook nie in die bronnelys nie. (Dit word egter geleidelik duidelik dat die probleem nie soseer by die teologie van Augustinus lê as by die 'teologie' van Paulus nie.)

22.Ook Luther moet skerp deurloop (Spangenberg 2009:38, 65, 225, 361, 366).

23. Die boek van Kennedy word besonder hoog aangeslaan deur die NH. Die somtotaal van Kennedy se teologie is: geloof in God en die aanvaarding van Jesus as voorbeeldige mens (Kennedy 2006:252-260).

24.Vergelyk in hierdie verband die klassieke studies van Sevenster (1946) en Cullmann (1959), en meer resent Van de Beek (1998) en Wessels (2006). Kyk ook Berkouwer (1952, 1953) en Jonker (1977). In hierdie artikel word veral gefokus op die titels en name van Jesus wat deur Spangenberg ter sprake gebring word. Cullmann (1959) bespreek die volgende: Profeet, Kneg van die Here, Priester, Messias, Seun van die mens, Here, Verlosser, Woord, Seun van God, God. König (2001) doen ongevee dieselfde. Vergelyk ook die verskillende Jesus-beelde van verskillende navorsers soos deur Wessels (2006) bespreek.
7:13, wat 'n ewige heerskappy en koninkryk ontvang. Nee, antwoord Spangenberg, Christene lees Daniël foutief as hulle dit in verband bring met Jesus en die koninkryk van God (ibid. 2009:70). ${ }^{25}$ Ander navorsers bring die titel wél in verband met Jesus en die koms van die koninkryk van God (sy koningsheerskappy), wat dui op die bomenslikheid, ja, goddelikheid van Jesus (König 2001:91-113).

Is Jesus dalk die beloofde Messias (Christus)? Ja, miskien nie die beloofde Messias van die Ou Testament nie, maar Hy word tog wel Messias/Christus genoem (Luk 9:20), hoewel dit niks met 'n drie-eenheid te doen het nie, ${ }^{26}$ en 'Christus' beteken gewoon 'Weldoener', so het ons gesien (Spangenberg 2009:281-282). Ook vir die Matteus-skrywer was Jesus, naas humanis en profeet, ook Messias (ibid. 2009:261), maar die Petrus-belydenis in Matteus 16:16 word nie diepgaande ontleed nie. ${ }^{27}$

Lukas verwys wel na Jesus as 'Verlosser', maar nie as Verlosser van sondes nie, maar van die keiserlike oorheersing (Spangenberg 2009:283). Die kruisdood van Jesus moet nie met versoening en vergewing van sondes in verband gebring word nie, want Jesus is as politieke aktivis en rebel deur die Romeine gekruisig, iets waarvan Paulus geen kennis gehad nie (ibid. 2009:26, 195, 201, 366).

Is Jesus dalk die Here? Ja, wel, só verwys minstens Lukas (2:11) na Hom, maar die implikasie van hierdie epogmakende belydenis, veral in die geskrifte van Paulus, word nie breedvoerig uitgespel nie (vgl. Spangenberg 2009:281-282; en vgl. ook hier Rom 10:9, 1 Kor 8:6, 12:3 en Fil 2:11.)

Die vroeë Christelike belydenis Kurios Jesous is in hierdie verband van besondere belang. Daarmee word nie net aansluiting gevind by Jahveh as God van Israel nie (in die Septuaginta word Jahveh en Adonai met kurios vertaal), maar word uitdrukking daaraan verleen dat Jesus oor groter mag as alle aardse magte, ook die Romeinse keiser (Kurios Kaisar), beskik. Hiermee word verwys na die lewende Here, die opgestane Here. 'n Dooie Here (Jesus) kan tog kwalik magtiger wees as 'n lewende keiser.

Soos Cullmann (1959:216) dit stel: 'The confession Kyrios Jesus is one of the most ancient we possess. The brief formula expresses the whole faith of the early Church with the single word Kyrios' (so ook ibid. 1959:216, 222, 233, 236). 'If Jesus was the Kyrios, then this influenced all other titles' (Cullmann 1959:320). Sevenster (1946:154) dink in dieselfde rigting: 'De benaming [kúrios] leent aan Christus een waardigheid toe, waardoor hij geheel aan God gelijk gesteld wordt' (so ook ibid. 1946:149-158) (vgl. verder Foerster 1965:1039-1058; Van de Beek 1998:107-123).

Hierdie belydenis bring die belangrikheid van die opstanding van Jesus na vore, 'n tema wat by die Jesus van Spangenberg

25.Botha (Spangenberg 2009:247) oordeel dat die 'Seun van die mens' verwys na ' $n$ bomenslike regter wat saam met God oordeel.

26.So ook Botha (Spangenberg 2009:239).

27.Vergelyk Ridderbos (1950:88-101). 
verdwyn. Spangenberg (2009:178) verwys byvoorbeeld daarna dat Paulus in 1 Tessalonisense na die opstanding van Jesus verwys, maar sê dan niks verder nie. Hy noem ook dat die kruis en opstanding in Paulus se brief aan die Romeine 'n 'kardinale rol' speel, want dit bevestig dat Hy die Messias en brenger van 'n nuwe tyd vir Israel is (ibid. 2009:186, 219). Maar hierdie 'kardinale belang' van die opstanding word nêrens uitgespel en ontwikkel nie, daar word slegs twee maal daarna verwys. As Spangenberg Matteus se Jesus bespreek (ibid. 2009:251-267), word nêrens na sy opstanding verwys nie. Nêrens word die opstandingsverhale van Lukas bespreek nie (ibid. 2009:269-293). Spangenberg sien die 'herverskyningsverhale' oor Jesus in die lig van die herverskynings van Moses en Elia as moedgewende verhale dat die koninkryk van God spoedig sal aanbreek (ibid. 2009:366-367). ${ }^{28}$ Klaarblyklik speel die liggaamlike opstanding van Jesus vir Spangenberg geen belangrike of deurslaggewende rol in die Evangelie van Jesus nie, en dít terwyl die vroegste evangelie aangaande Jesus (Hand 1-19) hoofsaaklik uit die boodskap van die opstanding bestaan het en die kruis later bygekom het (König 2009:117-127; König 2010a:102-106). ${ }^{29}$

Is Jesus die Seun van God en wat sou die implikasies daarvan wees? Ja, Hy word wel deur Lukas en Hebreërs 'Seun van God' genoem, maar nie in trinitariese konteks nie (Spangenberg 2009:281-282, 322, 325). Wat hierdie belydenis presies beteken, word egter nie ondubbelsinnig uitgespel nie.

Spangenberg is baie eksplisiet daaroor dat Jesus as Seun van God nie in trinitariese konteks verstaan mag word nie. ${ }^{30}$ Israel het nie so 'n gedagte geken nie ${ }^{31}$ (Spangenberg 2009:99, 127, 128) en vir Jesus self was dit 'n vreemde gedagte (ibid. 2009:362-363, 367). Ook Paulus het dit nie geken nie (ibid. 2009:174, 220), so ook Markus (ibid. 2009:239), Matteus (ibid. 2009:252), Lukas (ibid. 2009:281), Hebreërs (ibid. 2009:322, 325) en Openbaring (ibid. 2009:352, 357). ${ }^{32}$

Dat daar enige vorm van 'goddelikheid' in die persoon en werk van Jesus te bespeur was, moet volgens Spangenberg

28.0ok Botha (in Spangenberg 2009:233-250) sê niks oor die twee opstandingsverhale in Markus nie - die tweede is wel tekskrities onseker.

29.In een van sy jongste studies wys Spangenberg (2011c:551-558) die liggaamlike opstanding van Jesus af. Jesus se volgelinge het na sy kruisdood verhale oor herverskynings begin vertel as ' $n$ wyse om die hoop op die koms van die koninkryk lewendig te hou; en Paulus het met sy kruis- en opstandingsteologie eintlik 'n 'nuwe evangelie' geskep. Vir die belangrikheid van die liggaamlike opstanding van Jesus, vergelyk onder meer die volgende: Sevenster (1946:127-133, waar hy Jesus, vere 'visioene' afwys). Berkouwer (1953:196-218). Cullman hy ook die gedagte van 'visioene' afwys); Berkouwer (1953:196-218); Cullman (1959:207); Ridderbos (1966:46, 600-617) (kruis en opstanding as 'allesbeslissende middelpunt' vir Paulus); Bornkamm (1974:194-195); Berkhof (1990:305) ('Daarom taat en valt het christelijk geloof met de opstanding'); Pannenberg (1991:344) 'The resurrection of Jesus is the basis of Christian faith ...'); Strobel (1998:255 348, 354-361); N.T. Wright, soos aangehaal in Flew (2008:195-213) ('All the early Christians known to us for the first four or five generations believed in a future bodily resurrection, even though most of them came from the pagan world, where this was regarded as complete and utter rubbish'). Wright bied in hierdie boek van Flew (2008:195-213) 'n opsomming van sy omvattende boek The Resurrection of the Son of God (2003).

30.Botha merk op dat die uitdrukking 'Seun van God' by Markus op 'n regverdige persoon dui, maar met ' $n$ aspek van goddelikheid daarby (Spangenberg 2009:246247). Jacobs gee ook aandag aan Jesus as Logos, Seun van God en Seun van die mens (ibid. 2009:301-309).

31.'Gees van God' verwys in die Ou Testament na die krag van God (Spangenbers 2009:99).

32.Openbaring sien Jesus ook as 'Middelaar' tussen God en mens (Spangenberg 2009:362), maar Spangenberg gee nie uitgebreide aandag aan Middelaargedeeltes soos Hebreërs 8:6, 9:15 en 12:24 nie (vgl. ook 1 Tim 2:5). dus afgewys word. Wat egter nêrens deur Spangenberg bespreek word nie, is die vraag hoe dit moontlik kon wees dat monoteïstiese Christen-Jode daartoe oorgegaan het om Jesus te aanbid (Matt 28:9; Luk 24:52), 'n eer wat slegs God toegekom het. ${ }^{33}$

Die triniteitsgedagte is klaarblyklik vir Spangenberg 'n spekulatiewe idee wat onbybels en irrasioneel is en waarvan afstand gedoen behoort te word. Dit is daarom baie jammer dat Spangenberg nie moeite gedoen het nie om daardie Nuwe-Testamentiese gegewens waar eksplisiet na Jesus as 'God' verwys word, aan diepgaande ondersoek bloot te stel, soos onder meer Johannes 20:28, Romeine 9:5, Fillipense 2:6 en Hebreërs 1:8 (vgl. ook Tit 2:13; 1 Joh 5:20; 2 Pet 1:1). Die vraag moet ook aan Spangenberg gestel word of die triniteitsmotief, nie die triniteitsdogma nie, nie baie duidelik in die doopbevel van Matteus 28:19 en die seënbede van 2 Korintiërs 13:13 aangetref word nie. As die doopbevel in terme van die Jesusbeeld van Spangenberg herformuleer moet word, sal dit soos volg daar uitsien: Doop hulle in die Naam van God (die Vader) en die mens (Jesus) en die krag (die Heilige Gees). ${ }^{34}$ Maar so ' $n$ formulering is teologies absurd.

Spangenberg (2009:362-367) se finale konklusie is dat Jesus niemand anders was as 'n Joodse profeet en wysheidsleermeester nie. Dit is egter ironies dat hy hierdie beeld van Jesus grotendeels op grond van NuweTestamentiese tekste konstrueer wat hy aanvanklik as menslike en feilbare geskrifte gediskrediteer het.

Uit bogenoemde moet nie die afleiding gemaak word dat die klassieke triniteitsdogma 'n onveranderlike formulering is nie, trouens, dit werk met Griekse en Latynse filosofiese begrippe wat byvoorbeeld vreemd is in Afrika. Teoloë het 'n blywende opdrag om te bly soek na woorde en begrippe wat kontekstueel sinvol is, welwetend dat die essensie van dit wat in die triniteitsdogma bely word, nie mag verlore gaan nie asook dat die misterie van God nooit adekwaat in menslike woorde vasgevang kan word nie.

\section{Niks nuuts onder die son nie ? $^{35}$}

Die vraag wat onwillekeurig na vore kom, is die vraag of die moderne teologie inderdaad nuwe insigte oor Jesus na vore gebring het en of dit nie maar ou insigte herhaal nie, miskien met groter sofistikasie. Wie 'n blik werp op die dogmageskiedenis ${ }^{36}$ van die kerk, sal weet dat daar altyd 'n slingergang was tussen diegene wat die mensheid van Jesus beklemtoon het ten koste van sy goddelikheid (ebionitisme),

33.In verband met die Godheid van Jesus, vergelyk Berkouwer (1952:124-159) Cullmann (1959:234-237, 306-314); en Strobel (1998:208-228). Hurtardo (2005:203) wys daarop dat die verering van Jesus by die vroeë Christene geleë was in die feit van 'powerful revelatory experiences' wat hulle verstaan het as ontmoetings met die verheerlikte Christus. Hurtardo (2005:206) konkludeer dat Christene sal insien dat 'a historical appreciation of the emergence of devotion to Jesus need not pose a challenge to continuing to revere Jesus as rightful recipient of the devotion with God'.

34.Insgelyks moet die seënbede dan lui: Die genade van die mens (Jesus) en die liefde van God (die Vader) en die gemeenskap van die krag (die Heilige Gees) sal by julle almal wees.

35.Vergelyk in hierdie verband die briefwisseling tussen Murray Janson en Nico Smith (Smith 2010:179-201).

36.Dit is ironies dat Spangenberg, wat soveel klem lê op die 'historiese bewussyn' (Spangenberg 2009:268), geen historiese bewussyn toon vir die dogmageskiedenis van die kerk deur die eeue nie. 
enersyds, en andersyds, diegene wat sy goddelikheid ten koste van sy mensheid gehandhaaf het (dosetisme). En dan was daar natuurlik ook die Oosters Ortodokse ${ }^{37}$ en Westerse ${ }^{38}$ benadering wat beide aspekte beklemtoon het.

In die Vroeë Kerk was daar byvoorbeeld Arius (c. 256-336) wat die godheid van Jesus verwerp het, alhoewel hy nog bereid was om van Jesus se 'goddelikheid' te praat (Schulze 1978:50; Armstrong 1999:130).

In meer resente tye was daar ook godsdienstige bewegings wat die godheid van Jesus bevraagteken het, soos byvoorbeeld die Jehova Getuies (sedert 1931) (vgl. Stoker 1994:254-279).

Jesus, as mens, speel egter nie net in die Christelike tradisie 'n belangrike rol nie. Die Moslems erken Hom as ' $n$ baie belangrike profeet, hoewel nie belangriker as Mohammed nie (De Villiers in Van der Watt et al. 2012:165-166; Van de Beek 1998:271). Sommige Hindoes beskou Jesus as die geliefde seun van Krisjna wat aarde toe gekom het om mense se bewussyn van God te verhoog (De Villiers in Van der Watt 2010:167). ${ }^{39}$ Selfs vir die Neo-Marxis Machovec (1973) is Jesus 'n boeiende figuur. Hy beweer dat as hy in 'n wêreld sou moes leef wat die saak van Jesus heeltemal vergeet het, dan sou hy liewers nie wou leef nie. Uiteraard bestee NeoMarxiste veral aandag aan daardie fasette van die werk van Jesus wat by hulle referensiekader inpas, soos sy armoede, sy liefde vir die armes, sy hande-arbeid en sy versetsoptrede teen die status quo.

In nog meer resente tye, so het ons reeds opgemerk, het bewegings soos die 'Jesus Seminar' (1985) in die VSA en die Nuwe Hervorming (2002) in Suid-Afrika aandag gevestig op Jesus as (buitengewone) mens met ontkenning van sy godheid. Maar die 'belydenis' 'Jesus is (net) ware mens' is so oud soos die berge. Dít waarteen Johannes in sy briewe so ernstig gewaarsku het, naamlik die ontkenning dat Jesus Christus ware méns geword het (1 Joh 4:2; 2 Joh 7), dit wil sê die gnostisisme en dosetisme, is vandag nie meer die groot dispuutpunt nie. Die groot vraag tans is: Is Hy ook Goddelik? Het Gód self in Hom na die mens gekom? ${ }^{40}$

Dit is duidelik dat nie alle Jesus-bewonderaars is Christene nie.

\section{Kritiese debat}

Spangenberg het met sy boek oor Jesus 'n nuwe stimulus verleen aan die debat oor die persoon en werk van Jesus.

37.Spangenberg ignoreer die Oosters-Ortodokse teologie volledig. Vergelyk hier Staniloae (1984:259-260) wat die Drie-eenheid sien as 'Grundlage unseres Heils' (verlossing en 'vergoddeliking' van die mens.) Tshehla (2005:127-128) verkwalik (verlossing en 'vergoddeliking' van die mens.) Tshehla (2005:127-
Spangenberg weer dat hy die bydrae van Afrika-teoloë ignoreer.

38.Vergelyk hier onder meer Ratzinger and Pope Benedict XVI (2007:319-355).

39.Vergelyk hier die woorde van Gandhi (by Yancey 2005:155): 'Ek kon Jesus as ' martelaar aanvaar, die verpersoonliking van offerande en 'n goddelike leermeester, maar nie as die mees perfekte mens wat ooit gebore is nie. Sy dood aan die kruis was 'n groot voorbeeld vir die wêreld, maar dat daar enige misterieuse of wonderbaarlike deug daarin was, kon my hart nie aanvaar nie.'

40.Vergelyk in hierdie verband die opvatting van Paulus van Samosata, biskop van Antiogië: 'In Himself Jesus was nothing more than a mere human being, but He was filled with this pows was was filled with this power of God to such an extent that He was finally deified Durand 2007:38). Vir 'n soortgelyke benadering vergelyk ook Berkhof (1990:284285): 'Er zijn dus in Jezus geen twee subjecten, maar zijn menselijke ik is tot in de laatste uithoeken volkomen en uit vrije wil doordrongen van het ik van God ... God verdringt de menselijke persoon van Jezus niet, maar doordringt hem geheel met zijn Geest, dus met zichzelf.'
Vir 'n aantal sake wat hy aangeraak het, kan daar positiewe waardering wees, hoewel daar myns insiens teen sy vertrekpunte en hoofargumente radikale kritiek ingebring kan word.

\section{Positiewe waardering}

Veral twee aspekte kan in hierdie verband genoem word, naamlik die klem op die ware menslikheid van die Bybel asook die ware mensheid van Jesus.

Die Bybel is 'n boek wat nie uit die hemel geval het nie, maar wat deur mense van vlees en bloed geskryf is. Volgens Bavink (1928) het die openbaring van God:

[I]ngegaan in het creatuurlijke, in het leven en de historie van menschen en volken, in alle menschelijke vormen van droom en visioen, van onderzoek en nadenken, tot zelfs in het menschelijke zwakke en verachte en onedele toe ...' (bl. 405)

Die Heilige Gees het by die beskrywing van die woord van God 'niets menschelijk [heeft] versmaad, om tot orgaan te dienen van het goddelijke' (ibid. 1928:413-414). Dat Bavinck in die besonder en die gereformeerde teologie in die algemeen nie altyd daarin geslaag het om die slaggat van fundamentalisme te vermy nie, moet egter geredelik toegegee word. ${ }^{41}$

Deur middel van indringende en omvattende navorsing oor die Bybel en sy kultuurhistoriese agtergronde is talle nuwe insigte ontdek wat ons verstaan van die boodskap van die Bybel verryk en verdiep het (vgl. Wessels 2006:301307). Die ortodokse teologie is nie gekant teen volgehoue teologiese navorsing en nuwe insigte nie. Wat problematies is, is wanneer hierdie meer nuwe insigte die klassieke verstaan van die evangelie radikaal weerspreek en eintlik 'n ánder 'evangelie' word, sonder enige kontinuïteit met die voorafgaande insigte. ${ }^{42}$ In kort, wanneer dit 'n Umwertung aller Werte word.

Voorts is dit belangrik om vas te hou aan die ware mensheid van Jesus van Nasaret, wat in Betlehem gebore is, in Nasaret grootgeword het en in (veral) Galilea en Judea opgetree het en gekruisig is, en opgestaan het. Só 'n ware mens was Hy dat Hy deur die duiwel versoek kon word (Heb 2:18, 4:15) en dat Hy deur alles wat Hy gely het, moes leer wat gehoorsaamheid is (Heb 5:8). Die klassieke Christelike geloof was deurlopend anti-dosetisties. Vir 'n diepgaande begrip van Jesus is dit belangrik om deeglik rekening te hou met die Joodsheid van Jesus, met sy Godsvertroue en medemenslikheid, hoewel dit nie ál is wat van Hom gesê (en bely) kan word nie.

\section{Radikaal-kritiese vrae}

Minstens drie vrae kan in hierdie verband gevra word.

\section{Die eerste is: Waarom is die Bybel nog nodig?}

Dit is duidelik dat die Bybel vir Spangenberg ' $n$ boek 'onder andere' is, ' $n$ boek wat dus geen openbaring van God bevat nie, maar slegs menslike woorde wat aan die mees radikale Skrifkritiek blootgestel kan word.

41.Vergelyk hier hoe die beleid van apartheid in Suid-Afrika teologies regverdig is. Kyk Vorster (2008).

42.Wessels (2006:301) meen daar is tog méér kontinuïteit tussen die historiese Jesus en die verkondigde Christus as wat vermoed is. 
In hierdie verband kan veral gedink word aan Spangenberg se hantering van Paulus en Hebreërs. Spangenberg (2009) huiwer nie om te sê dat Paulus in sy Romeinebrief OuTestamentiese tekste doelbewus 'ombuig' (ibid. 2009:185), 'plooi' (ibid. 2009:187, 205), 'jakkalsdraaie in sy redenasies gooi' (ibid. 2009:187, 190) en soms 'op twee stoele sit' nie (Rom 9-11) (ibid. 2009:208). Paulus se verklaring waarom mense sterf (erfsonde) is ook foutief (Rom 5:12) (ibid. 2009:213-214). ${ }^{43}$ 'Dis duidelik dat Paulus se woorde nie God se woorde is nie en dat sy kennis allermins God se kennis is' (ibid. 2009:213). ${ }^{44}$ Daarby het Paulus ook nie 'n 'vrouvriendelike teologie' beoefen nie (ibid. 2009:213).

Dieselfde soort kritiek vind ons by Spangenberg ten opsigte van die Hebreërsbrief se skrywer. Hy interpreteer die Tenak 'soos dit hom pas' (Spangenberg 2009:318), hy ontjoods die hele Ou Testament en verchristelik dit daarna (ibid. 2009:324). Die skrywer gebruik soms 'rare argumente' (ibid. 2009:332) en hy maak Psalm 110 foutiewelik op Jesus van toepassing (ibid. 2009:332). Spanenberg (ibid. 2009:334) reken dat, volgens Hebreërs, Jesus nie aan die kruis vir sondes gesterf het nie (vgl. Heb 10:22). Tog gee Spangenberg nie aandag aan uitsprake in Hebreërs 9:12, 14-15, 28 en 10:12, 14 nie..$^{45}$

Dit is egter één saak om teologies na te dink oor die wyse waarop die Nuwe-Testamentiese skrywers die Ou Testament aanhaal en Christologies dui, en heeltemal 'n ánder saak om daardie duiding as doelbewuste verdraaiing en verwringing van die Ou Testament te tipeer. ${ }^{46}$

Wat verder by Spangenberg hinder, is nie net sy hiperkritiese omgang met die Bybel nie, maar ook sy selektiewe omgang met die Skrifgegewens. Ons noem hier enkele voorbeelde.

Volgens Spangenberg het Paulus sewe briewe geskryf (Spangenberg 2009:137), maar waarom behandel hy net vier daarvan? Hoewel Spangenberg opmerk dat die kruisdood én opstanding van Jesus vir Paulus van kardinale belang is (ibid. 2009:168, 219), verwys hy in sy bespreking van Paulus (ibid. 2009:163-220) net twee maal daarna, terwyl dit in Romeine minstens vier keer genoem word (1:4, 6:5, 4:25, 8:34). Dit sluit die talle ander plekke in die Pauliniese korpus (veral 1 Kor 15) uit. ${ }^{47}$

Volgens Spangenberg was Jesus net 'n (Joodse) mens en nie goddelik nie, maar hy bespreek nêrens die vraag wat

43.Spangenberg verset hom deurlopend teen die 'erfsondeleer' van Augustinus en die Westerse teologie (Spangenberg 2009:23, 51, 53, 128, 212-213). Indien ' $n$ mens Westerse teologie (Spangenberg 2009:23, $51,53,128,212-213)$. Indien ' $n$ mens
die diepste intensie van 'erfsonde' beskryf as 'alle mense is sondaars', dan maak die diepste intensie van 'erfsonde' beskryf as 'alle mense is sondaars', dan maak
Chesterton (2006:10) se opmerking sin: 'Certain new theologians dispute original Chesterton (2006:10) se opmerking sin: 'Certain new theologians dispute original
sin, which is the only part of Christian theology which can really be proved.' Dit is sin, which is the only part of Christian theology which can really be proved.' Dit is
die maklikste ding ter wêreld om (wetenskaplik) te bewys dat alle mense sondaars die maklikste ding ter wêreld om (wetenskaplik) te bewys dat alle mense sondaa
(d.w.s. gebroke, geskonde, geknakte, gesplete, ja, onvolmaakte wesens) is.

44.Klaarblyklik weet Spangenberg meer van 'God se kennis' as wat Paulus daarvan geweet het. Vergelyk ook Jacobs se opmerking dat die uitsprake wat die Johannesskrywer in hoofstuk 8 in die mond van Jesus lê, 'kru, afstootlik en mensonwaardig' is (Spangenberg 2009:313).

45.Vergelyk hierteenoor die studie van Andrie du Toit (2002) oor Hebreërs.

46.Vergelyk onder andere Grosheide (1929: 50-51, 108, 188-190, 230-240).

47.In sy omvattende studie oor die 'teologie' van Paulus konkludeer Ridderbos $(1966: 34)$ dat die beheersende motief in die prediking van Paulus bestaan in die heilryke handeling van God in die koms en werk en in besonder, in die dood en opstanding van Christus. Die kruis en die opstanding van Christus is die 'allesbeheersende middelpunt' (kyk ibid. 1966:600-617). dit impliseer dat Jesus na sy opstanding 'aanbid' is nie (Matt 28:9; Luk 24:52; 2 Kor 12:8; Op 5:13). Daar word wel hierna verwys (Spangenberg 2009:286), maar daar word nie uitgebrei op die vraag hoe dit gekom het dat monoteïstiese Jode ' $n$ Joodse rabbi kon begin aanbid het nie (vgl. Bavinck 1929:304-305; Heyns 1992:130-138).

Volgens die skrywer ken die Nuwe Testament geen triniteitsdogma nie, maar hy bespreek nêrens die vraag of die triniteitsmotief nie reeds in tekste soos Matteus 28:19, 1 Korintiërs 8:6, 2 Korintiërs 13:13 en Openbaring 1:4-6 aanwesig is nie. Jesus sterf volgens Hebreërs nie vir ons sondes aan die kruis nie (Spangenberg 2009:334), maar die gegewens in Hebreërs 9:12, 14-15, 28; 10:12, 14 word nie in diepte bespreek nie. Hoewel daar in die boek hier en daar na die werk van die Heilige Gees verwys word (Spangenberg 2009:136, 193, 274, 291), word die werk van die Gees nêrens in verband gebring met die inspirasie, inskripturasie of interpretasie van die Bybel nie. Dit is ook opvallend dat daar in die Waardes van die NH nêrens na die Gees van God verwys word nie.

Die Bybel bevat dus slegs ménslike gedagtes en ménslike woorde oor God sodat daar van die gedagte van openbaring van God aan die mens geen sprake kan wees nie. ${ }^{48}$ Die Bybel is 'n boek 'onder andere', een van vele boeke, almal op gelyke vlak. Dán is die vraag onvermydelik. Waarom dan juis aan die Bybel soveel aandag en tyd bestee. Waarom jou hele lewe daarmee besig wees, en daarmee jou lewensonderhoud verdien? Nêrens word hierdie vraag voldoende deur Spangenberg beantwoord nie, behalwe om op te merk dat hy met die Bybel grootgeword het. (vgl. sy epos aan my op 02 November 2010) Maar dis tog nie 'n wetenskaplikgefundeerde en verantwoordbare standpunt nie.

As die Bybel nie 'n normatiewe teks is nie, vanweë sy bevrydende boodskap en die bevestiging daarvan in my hart deur die Gees, is die Christelike teologie en die Christelike geloof 'n teologie en geloof 'onder andere' en het dit sy uitsonderlike karakter verloor. Waarom jou dan nog daarmee besig hou?

\section{Die tweede vraag is: Waarom nog vir Jesus kies?}

As ons te doen het met 'n Jesus 'onder andere', soos die eerste Waarde van die NH en ook Spenenberg se betoog, waarom dan soveel aandag aan juis Jesus bestee? Waarom nie eerder kies vir Boeddha of Gandhi nie? Om na Gandhi te verwys (vgl. Yancey 2005:132-157); hy het mooi dinge geleer, hy het voorbeeldig en vredeliewend en onselfsugtig geleef en hy het 'n martelaarsdood gesterf. Waarom moet ek juis vir Jesus bo Gandhi kies as oriënteringspunt van my lewe? Spangenberg antwoord hierop: ek het so grootgeword, ${ }^{49}$ maar dis nie 'n

48.Vergelyk hier die skerp uitspraak van Bavinck (1908:143): religie rus op openbaring, want daarsonder sak alles terug in 'eene verderfelijke superstitie'.

49. In ' $n$ vraag van my aan Spangenberg of Gandhi en Boeddha net so belangrik is as Jesus en waarom Jesus belangriker as hulle sou wees, antwoord hy per epos ( 02 November 2010): 'Geen mens kies sy vel, sy taal, sy kultuur of sy godsdiens nie. Dit word alles met geboorte aan hom gegee.' Spannenberg (2011b:30, 31) beskou die word alles met geboorte aan hom gegee. 'spannenberg (2011b:30, 31) beskou die Bybel en Jesus as 'deel van my kulturele erfenis' wat hy nie wil nalaat nie. Maar
' $\mathrm{n}$ antwoord wat nie kan standhou voor die vrae van 'n kritiese teologie nie. 
aanvaarbare en verantwoorde standpunt nie. In elk geval het hy afskeid geneem van die klassieke kerklike belydenis van Jesus, dus van sy meerwaardigheid, sy goddelikheid..$^{50}$ Spangenberg kies vir 'n Jesus 'onder andere', een van die talle antwoorde op die vraag na 'die goddelike'. Dit laat die vraag ontstaan of daar' $n$ fundamentele verskil is tussen Spangenberg se siening van Jesus en dié van 'n Moslem of Gandhi wat Jesus ook as voortreflike mens en profeet aanvaar?

Die implikasie van Spangenberg se benadering is dat alle sendingwerk in die verlede en hede, waar bevryding van sonde en dood in die Naam van Jesus Christus verkondig is, onnodig en oorbodig was en is (vgl. Bosch 1991; Kraemer 1960). ${ }^{51}$

In hierdie verband moet ook daarmee rekening gehou word dat Afrika nog nooit werklik kennis gemaak het met die volle krag van die Aufklárung van die 18de eeu nie. Afrika verkeer grotendeels nog in 'n premoderne fase. Dis maar eers onlangs dat die rasionalisme van die Verligting Afrika (en veral Suid-Afrika) in volle sterkte getref het. Dit is vir my onvoorstelbaar hoedat die evangelie van God se genade in Christus in sy gesofistikeerde en geontmitologiseerde vorm sinvol aan tradisionele Afrikane gebring kan word, tensy ons ' $n$ 'dubbele' evangelie verkondig, een in eenvoud aan premoderne mense en een in al sy kompleksiteit aan (post-) moderne mense. Maar dis nie wat Paulus gedoen het nie (Rom 1:14). (Aan die ander kant: vir die NH is die uitdra van die evangelie nie nodig nie.)

\section{Die derde vraag is nou onvermydelik: Waarom moet ek nog in God glo ? $^{52}$}

Hierdie vraag is nie sommer uit die lug gegryp nie, maar dis 'n werklike vraag wat ateïste aan die liberale teologie stel. Die ateïs Pellencin (2007:129) voer aan dat liberale teoloë betoog dat die (klassieke) Christelike leer in konflik is met die menslike verstand en dat hulle nou die Christelike geloof herinterpreteer om dit vir die verstand aanvaarbaar te maak. In die proses maak hulle egter nie net ' $n$ 'groteske karikatuur' van die Christelike geloof nie, maar hulle misluk ook om rede en geloof te versoen. ${ }^{53}$

Die hiperkritiese teologie, wat (naïewe) rasionalisme en positivisme as vertrekpunt neem, staan voor die enorme uitdaging hoe voorkom kan word dat so 'n standpunt nie op agnostisisme en ateïsme uitloop nie. In die negentiende eeu het D.F. Strauss die konsekwensies van sy vrydenkende Jesus-teologie getrek en ateïs geword. ${ }^{54}$ God is immers nie

50. Vergelyk hierteenoor die omvattende studie van Du Rand (2007) oor Openbaring.

51.Vir Kraemer $(1960: 81,83,107)$ is slegs Jesus Christus en sy Ryk die verborge middelpunt van die geskiedenis.

52.Spangenberg (2011b:13) meld dat die nuwe debat verskuif van die vraag wie Jesus was (naamlik nié ware God en ware mens nie) na die vraag wie God is (naamlik nié Drie-eenheid nie). Hiermee bereik die debat sy diepste punt en dis nie onwaarskynlik dat die resultaat gaan wees dat die teologie nie verder kan kom as om van 'die goddelike' te praat nie. Maar wat beteken dit en hoe bid ' $n$ mens tot 'die goddelike' (of val die gebed weg)? In ' $n$ gesprek met Van der Merwe (2011:3) merk Spangenberg op dat hy nog 'die tradisionele tafelgebed doen as ons as gesin saam aan tafel is', want hy ervaar so 'n saamwees as 'amper 'n religieuse oomblik'. Ek moet openhartig sê dat ek so 'n benadering nie begryp nie. Vergelyk ook Kuitert (1998:311) in hierdie verband: 'Wie is God? Dat blijft bij de christologie die ik voorsta, de enige echte centrale vraag.'

53.Vergelyk in hierdie verband ook die atëistiese benadering van Claassen (2008). Een van die groot eksponente van moderne ateïsme is natuurlik Dawkins (2007).

54. Dit is opvallend dat Willie Esterhuyse (2010:61) daarvan melding maak dat hy juis deur die 'vrysinnige' teoloog J. Sperna Weiland beïnvloed is. rasioneel bewysbaar en verifieerbaar nie, natuurlik ook nie falsifieerbaar nie.

\section{Gevolgtrekking 'Alternatiewe geloof'?}

Teen die einde van sy boek maak Spangenberg (2009:369-370) die volgende opmerking: 'Diegene wat nie meer met die Jesus van die ekumeniese belydenisse (of die dogmatiese Jesus) kan identifiseer nie, het hulleself nie buite die Christendom geplaas nie. Inteendeel. ${ }^{\prime 55}$ Maar dít is juis die vraag op die tafel, gesien ook in die lig van die voorkeur vir die gebruik van die naam 'Jesus' in plaas van die naam 'Christus' of 'Here' by die NH. Dus, iemand wil 'n 'Christen' wees, maar hy huiwer om die naam 'Christus' te gebruik ${ }^{56}$ Ons het hier egter nie meer te doen met die klassieke Christologie soos wat dit vir twee duisend jaar deur Oosterse en Westerse Christene verstaan is nie, maar eerder met 'n Jesulogie en daarom met Jesuïete (of dan Neo-Jesuïete, om hulle van die Jesuïete in die Rooms-Katolieke Kerk te onderskei). Ons het hier immers met 'n paradigmaskuif van ontsaglike grootte in die teologie te doen, wég van die klassieke verstaan van die persoon en werk van Jesus Christus, van die analogia fidei, van Jesus as Heiland en Here, na Jesus as voorbeeldige mens. ${ }^{57} \mathrm{Na}$ 'n noukeurige analise van die standpunte van die NH kom Durand (2005:107) tot die onthutsende konklusie dat ons hier met ' $n$ 'alternatiewe geloof' te doen het. ${ }^{58}$

My konklusie is dat ons hier met twee verskillende geloofsoortuigings te doen het, ${ }^{59}$ al het albei besondere belangstelling in die persoon en werk van Jesus van Nasaret. Vir die een is Jesus Heiland en Here, Verlosser en Middelaar, vir tyd en ewigheid; vir die ander is Hy 'n mooi voorbeeld, vir hier en nou. ${ }^{60}$ Die een werk met ' $n$ Christologie, die ander met' $n$ Jesulogie en beide moet duidelik van mekaar onderskei word. ${ }^{61}$

55.Spangenberg (2002b:192; vgl. 2003:148) merk op dat Bybelwetenskaplikes nie die Bybel wil weggooi en die geloof ondermyn nie, maar dit help herformuleer. Hy formuleer in hierdie verband sestien 'voorlopige geloofstellings' (ibid. 2003:157-159). Dit is interessant om hierdie sestien stellings met die nege Waardes van die NH te Dit is interessant om hierdie sestien stellings met die nege Waardes van die NH te vergelyk. Basies handel die sestien stellings oor: die Bybel (as menslike geskrif), God, Jesus (as mens) en die koninkryk van God. Die soendood van Jesus en sy
opstanding val weg - en daar is ook geen verwysing na 'n eskatologiese verwagting nie.

56.Dit val op dat Spangenberg (2002a:88-111) in sy bydrae tot die boek 'Die Nuwe Hervorming' nêrens na Christus verwys nie, maar slegs na Jesus (hoewel hy tog van 'Christene' praat)

57.Spangenberg gee toe dat ons 'vanuit twee verskillende paradigmas' die Bybel, die dogmas en die belydenisse benader en hy verkies om hom eerder as ' $n$ 'Christelike humanis' as 'Jesuïet' te tipeer (epos aan my op 19 Julie 2011). Hierdie humanisme verskil egter grondig van die 'Christelike humanisme' wat De Gruchy (2011:14-17) bepleit.

58.Reeds in 1946 het Sevenster (1946:363) in dieselfde rigting gedink: 'Blijkbaar wil men in deze moderne concepties [oor die Christologie] toch steeds iets geheel anders tot uitdrukking brengen, dan de oudste kerk heeft bedoeld' (my kursivering, J.H. v. W.). Vir'n bespreking van die NH, vergelyk Van Wyk (2003:345-373).

59.Spangenberg (2006:361-373) vereenselwig hom met die opmerking van Sullivan dat ' $n$ groter gaping as die Grand Canyon bestaan tussen wat Jesus geglo het en wat die ortodokse Christendom oor hom glo; wat die kerk aangaande Jesus glo, is nie dieselfde as wat Jesus oor homself geglo het nie. Spangenberg (2011b:11) konkludeer: 'Daar is dus binne alle Christelike denominasies dwarsoor die wêreld tans twee groepe gelowiges' (ortodoks en heterodoks). Die formulering is myns insiens ' $\mathrm{n}$ growwe veralgemening.

60.Vir die NH val die (individuele en kosmiese) eskatologie weg. Die lewe eindig met die dood (Spangenberg 2011a:2).

61 Ons het tans nie net meer met ' $n$ blote teologies-dogmatiese vraagstelling te doen nie maar veral ook met ' $n$ teologies-etiese: hoe kan ' $n$ teoloog nog met ' $n$ skoon gewete in ' $n$ kerkgemeenskap aanbly (met al die voordele daaraan verbonde) warin die klassieke Christologie bely en verkondig word, terwyl hy of sy radikaal daarvan afskeid geneem het? Hierdie kritiese vraag raak nie vir Spangenberg nie, aangesien hy die NGK reeds eerder verlaat het. 
Hierdie konklusie mag egter nie in selfvoldaanheid en hovaardigheid getrek word nie. Die skoonste belydenis sonder die grootse daad is immers leeg. 'Nie elkeen wat vir My sê "Here, Here", het Jesus gesê, sal in die koninkryk van die hemel ingaan nie, maar net hy wat die wil doen van my Vader wat in die hemel is' (Matt 7:21). Ortodoksie en ortopraksie vorm 'n onlosmaaklike eenheid. Jesus is Verlosser én Voorbeeld; geloof ín Jesus Christus en navolging ván Christus is twee onskeibare dele van dieselfde munt. ${ }^{62}$ Solank daar by 'Jesuïete' meer gesien word van die navolging van Jesus as by (klassieke) Christene, is dit 'n ope vraag of laasgenoemde sy persoon en werk reg verstaan het.

\section{Erkenning \\ Mededingende belang}

Die outeur verklaar dat hy geen finansiële of persoonlike verbintenis het met enige party wat hom nadelig kon beïnvloed in die skryf van hierdie artikel nie.

\section{Literatuurverwysings}

Armstrong, K., 1999, A History of God, From Abraham to the Present: The 4000-year Quest for God, Vintage Books, London.

Atanasius: St. Athanasius on the Incarnation, The Treatise De incarnatione verbi Dei, 1970, transl. 'A Religious of C.S.M.V.', Mowbray, London.

Barrett, P., 2000, Science and theology since Copernicus: The search for understanding, Unisa, Pretoria.

Bavinck, H., 1908, Wijsbegeerte der Openbaring, Kok, Kampen.

Bavinck, H., 1928/1929, Gereformeerde Dogmatiek, Deel 1/2, Kok, Kampen.

Berkhof, H., 1990, Christelijk geloof: Een inleiding tot de geloofsleer, Callenbach, Nijkerk.

Berkouwer, G.C., 1952, De Persoon van Christus, Kok, Kampen.

Berkouwer, G.C., 1953, Het Werk van Christus, Kok, Kampen.

Bonhoeffer, D., 1968 [1937], Navolging, transl. E.A. Franken-Duparc, Ten Have, Amsterdam.

Bornkamm, G., 1974, Jesus van Nasaret, transl. A.B. du Toit, Verenigde Lutherse Seminarie, Kaapstad.

Bosch, D.J., 1991, Transforming Mission, Paradigm Shifts in Theology of Mission, Orbis Books, New York.

Chesterton, G.K., 2006, Orthodoxy, Hendrickson, Peabody.

Claassen, G., 2008, Geloof, bygeloof en ander wensdenkery, Protea, Pretoria.

Craffert, P.C., 2008, The life of a Galilean Shaman: Jesus of Nazareth in anthropologicalhistorical perspective, Cascade, Eugene.

Cullmann, O., 1959, The Christology of the New Testament, transl. S.C. Guthrie \& C.A.M. Hall, SCM Press, London.

Dawkins, R., 2007, The God Delusion, Black Swan, London.

De Gruchy, J.W., 2011, 'Transforming Traditions, Doing Theology in South Africa Today' [Transformerende tradisies, teologie-beoefening in Suid-Afrika vandag], Journal of Theology for Southern Africa 139, 7-17.

Du Plessis, I., 2005, Jesus: Die keuse: Eerlike geloofsvrae oor die Jesusgesprek, Lux Verbi.BM, Wellington.

Durand, J.J.F., 2005, Doodloopstrate van die geloof: 'n Perspektief op die Nuwe Hervorming, Rapid Access, Stellenbosch.

Durand, J., 2007, The many Faces of God, Highways and byways on the route towards an orthodox image of God in the history of Christianity from the first to the an orthodox image of God in the history of
seventeenth century, Sun Press, Stellenbosch.

Du Rand, J., 2007, Die A-Z van Openbaring, 'n Allesomvattende perspektief op die boek Openbaring, CUM, Vereeniging.

Du Toit, A., 2002, Hebreërs vir vandag, 'n Bybelstudie vir dieper delwers, CUM, Vereeniging.

Du Toit, C.W. (ed.), 1997, Images of Jesus, Unisa, Pretoria.

Duvenage, S.C.W., 1954, Die navolging van Christus, Pro Rege, Potchefstroom.

Esterhuyse, W., 2009, God en die gode van Egipte, In die voetspore van die onsienlike, Lux Verbi.BM, Wellington.

Esterhuyse, W., 2010, Die God van Genesis ... drama in die amfiteater van die Oneindige ..., CMP, Durbanville.

Flew, A., 2008, There is a God, How the World's most notorius Atheist changed his mind, HarperCollins, New York (including chapters by R.A. Varghese \& N.T. Wright).

Foerster, W., 1965, kúrios, in G. Kittel, (ed.), Theological Dictionary of the New Testament, transl. G. W. Bromiley, pp. 1039-1058, Eerdmans, Grand Rapids.

62.Vergelyk onder andere Bonhoeffer (1968 [1937]) en Duvenage (1954).
Grosheide, F.W., 1929, Hermeneutiek ten dienste van de bestudeering van het Nieuwe Testament, Bottenburg, Amsterdam.

Heyns, J.A., 1992, Inleiding tot die dogmatiek - aan die hand van die Nederlandse Geloofsbelydenis, NG Kerkboekhandel, Pretoria.

Hurtardo, L.W., 2005, How on earth did Jesus become a God? Historical Questions about Earliest Devotions to Jesus, Eerdmans, Grand Rapids.

Janson, M., 2001, Op soek na die ware Jesus, Lux Verbi.BM, Wellington.

Jonker, W.D., 1977, Christus, die Middelaar, NG Kerkboekhandel, Pretoria.

Joubert, S., 2009, Jesus: 'n Radikale sprong, CUM, Vereeniging.

Kennedy, P., 2006, A modern introduction to theology: New questions for old beliefs, Taurus, London.

König, A., 2001, Die helfte is my nooit oor Jesus vertel nie: 'n Nuwe kyk op die een wat jou lewe verander, Lux Verbi.BM, Wellington.

König, A., 2009, Die evangelie is op die spel: Die verwarring oor die Bybel, en oor Jesus se lewe, sterwe en opstanding: 'n alternatief op liberalisme en fundamentalisme, Lux Verbi.BM, Wellington.

König, A., 2010a, Wat kan ek glo? CUM, Vereeniging.

König, A., 2010b, Alle paaie lei na Jesus, Hoe die groot temas van die Bybel op Jesus uitloop, CUM, Vereeniging.

Kraemer, H., 1960, Waarom nu juist het Christendom? Callenbach, Nijkerk.

Kuitert, H.M., 1974, Zonder geloof vaart niemand wel: Een plaatsbepaling van Christendom en kerk, Baarn, Ten Have.

Kuitert, H.M., 1998, Jezus: Nalatenschap van het Christendom, Schets voor en christologie, Baarn, Ten Have.

Machovec, M., 1973, Jezus voor atheïsten - met een inleiding van Helmut Gollwitzer, Baarn, Ten Have.

McLaren, B., 2010, A new kind of Christianity, Ten questions that are transforming the faith, Hodder \& Stroughton, London.

Mofokeng, T.A., 1983, The Crucified amongst the Crossbearers, Towards a black Christology, Kampen, Kok.

Muller, P. (red.), 2002, Die Nuwe Hervorming, Protea, Pretoria.

NG Kerk, 1997, Ons Glo ...: Die Drie Fromuleire van Eenheid en Ekumeniese Belydenisse, NG Kerk-Uitgewers, Kaapstad.

Nolan, A., 1976, Jesus before Christianity, The Gospel of Liberation, David Philip, Cape Town.

Nolan, A., 2006, Jesus Today: A Spirituality of Radical Freedom, Orbis Books, Maryknoll NY.

Pannenberg, W., 1991, Systematic Theology, Vol. 2, transl., G.W. Bromiley, Eerdmans, Grand Rapids.

Pellencin, A.L., 2007, Ateïsme: Die saak teen God, Publiself, Pretoria.

Polman, A.D.R., s.a., Onze Nederlandsche Geloofsbelijdenis, Verklaard uit het verlede, geconfronteerd met het hede, Deel I, Franker, Wever.

Ratzinger, J., Pope Benedict XVI, 2007, Jesus of Nazareth, From Baptism in the Jordan to the Transfiguration, Bloomsbury, London.

Ridderbos, H., 1950, De Komst van het Koninkrijk, Jezus' Prediking volgens de synoptische Evangeliën, Kampen, Kok.

Ridderbos, H., 1966, Paulus, Ontwerp van zijn theologie, Kampen, Kok.

RKK: Rooms-Katolieke Kerk: Constituties en Decreten van het Tweede Vaticaans Oecumenisch Concilie, 1967, Katholiek Archief, Amersfoort.

Satterthwaite, P.E., Hess, R.S. \& Wenham, G.J. (eds.), 1995, The Lord's anointed: interpretation of Old Testament Messianic texts, Grand Rapids, Paternoster.

Schulze, L.F., 1978, Geloof deur die eeue, NG Kerkboekhandel, Pretoria.

Schutte, F., 2008, Jesus' resurrection in Joseph's garden: a postmodern revisit, Protea, Pretoria.

Seeberg, R., 1964, Text-book of the History of Doctrines (1), Eerdmans, Grand Rapids.

Sevenster, G., 1946, De Christologie van het Nieuwe Testament, Holland Uitg., Amsterdam.

Smith, N., 2010, Mosaïek van mense, Onmoetings wat my denke en lewe radikaa verander het, Bybel-Media, Wellington.

Spangenberg, I.J.J., 1985, 'Die Christologiese uitleg van die Ou Testament en die implikasies vir die prediking', Scriptura 16, 29-46.

Spangenberg, I.J.J., 1994, 'Paradigmaveranderinge in die Bybelwetenskappe, 'n Bydrae tot die gesprek tussen die Bybelwetenskappe en Sistematiese Teologie', Religie en Teologie (1\&2), 144-184.

Spangenberg, I.J.J., 1998, Perspektiewe op die Bybel, God se Woord in mensetaal, Van Schaik, Pretoria.

Spangenberg, I.J.J., 2002a, 'Die Bybel en die Nuwe Hervorming' in P. Muller (red.), Die Nuwe Hervorming, pp. 88-111, Protea, Pretoria.

Spangenberg, I.J.J., 2002b, 'Hoe dink vandag se mense oor die Bybel?', Verbum et Ecclesia 23(1), 183-195.

Spangenberg, I.J.J., 2002c, 'Beleef die Christelike teologie soos met die vorige eeu weer 'n paradigmaverskuiwing?', HTS Teologiese Studies 58(1), 100-117.

Spangenberg, I.J.J., 2003, 'Wat moet ons weet en wat kan ons glo?', Ned Geref Teologiese Tydskrif 44 (1\&2), 147-160. 
Spangenberg, I.J.J., 2006, 'Oor doodloopstrate en omweë: Kanttekeninge by die boek - Doodloopstrate van die geloop - 'n Perspektief op die Nuwe Hervorming', Verbum et Ecclesia 27, 361-373.

Spangenberg, I.J.J., 2009, Jesus van Nasaret, Griffel, Kaapstad (met die medewerking van Pieter Botha en Maretha Jacobs).

Spangenberg, I.J.J, 2010a, epos, 02 November 2010.

Spangenberg, I.J.J, 2010b, epos, 25 November 2010.

Spangenberg, I.J.J., 2011a, 'Brief: Niks leef voort ná die dood', Beeld/By, 2, 28 Feb.

Spangenberg, I.J.J., 2011b, Die Jesus Seminaar vier sy eerste kwarteeu: nabetragtings van 'n buitenstander, besigtig op 15 Mei 2011(1-22), van http://www.litnet. co.za/cgi-bin/giga.cgi?cmd=cause_dir_news_item\&cause_id=1270\&news id103440\&cat_id=1905

Spangenberg, I.J.J. 2011c, 'Opstandingsverhale en opstandingsdogma', HTS Teologiese Studies, 67(1), 551-558.

Spangenberg, I.J.J., 2011d, epos, 18 Julie, spangijj@unisa.ac.za.

Staniloae, D., 1984, Orthodoxe Dogmatik, transl. H. Pitters, Benziger Verlag, Zürich.

Stoker, H.G., 1994, Die Jehovah-Getuies: 'n Onchristelike Kulte?, Th.D. Proefskrif, PU CHO Potchefstroom.

Strobel, L., 1998, The Case for Christ, A Journalist's personal Investigation of the Evidence for Jesus, Zondervan, Grand Rapids.

Stylianopoulos, T.G., 2008, 'Scripture and tradition in the church' in M.B. Cunningham \& E. Theokritoff (eds.), Orthodox Christian theology, pp. 21-34, Cambridge University Press, Cambridge. http://dx.doi.org/10.1017/CCOL9780521864848.002

Tshehla, S., 2005, 'Book review: Izak Spangenberg: Perspectives on the Bible' [Boekresensie: Izak Spangenberg: Perspektiewe op die Bybel], Journal for Theology for Southern Africa 122, 127-128.
Van Aarde, A., 2001, Fatherless in Galilee: Jesus as Child of God, Trinity, Harrisburg. Van de Beek, A., 1998, Jezus Kurios, De Christologie als hart van de theologie, Spreken over God, reeks 1, deel 1, Kok, Kampen.

Van der Merwe, K., 2011, 'Middagete met Sakkie Spangenberg, Hoe slaap dominee dan?', Beeld/By 3, 26 Maart.

Van der Walt, T., 2006, Die Messias het gekom!' $n$ Gids in die evangelies vir toegewyde Bybel-studente, Potchefstroomse Teologiese Publikasies, Potchefstroom.

Van der Watt, J. (red.), Joubert, S., Tolmie, F. \& De Villiers, P., 2010, Wie sê julle is Ek? Jesus deur die oё van ander, CUM, Vereeniging.

Van Niekerk, A.A., 2005, Geloof sonder sekerhede: Besinning oor eietydse gelowiges, Lux Verbi BM., Wellington.

Van Niekerk, A.A., 2007, 'Oor tradisie, hermeneutiek en wetenskap: Mistastings in Sakkie Spangenberg se lesing: Geloof sonder sekerhede: besinning vir eietydse gelowiges', Nederduits Gereformeerde Teologiese Tydskrif 48(3\&4), 674-685.

Van Wyk, J.H., 2003, 'Die Nuwe Hervorming: Verwagting of verydeling?', In die Skriflig 37(3), 345-373.

Vorster, J.M., 2008, The challenge of contemporary religious fundamentalism, Pretoria, Unisa.

Wessels, F., 2006, Wie was Jesus regtig? Oor die historiese Jesus, Lux Verbi BM., Wellington.

Wright, N.T., 2003, The Resurrection of the Son of God, vol. 3, Fortress Press, Minneapolis, MN.

Yancey, P., 2005, Spirituele Oorlewing, Hoe my geloof die kerk oorleef het, CUM, Vereeninging. 